excellent Danish screening procedures to identify samples of individuals with Klinefelter's, Turner's and the XYY Syndrome which are much more representative than those usually culled from mental or criminal institutions. Not surprisingly they report that although there are distinct disabilities, eg the passivity and dependence of Klinefelter males, their intellectual and social performance is better than generally believed. True, a community-based prospective study from Edinburgh not only confirms the higher risk of intellectual deficit in girls with the $\mathrm{XXX}$ constitution but also reports persistent temper tantrums in boys with XYY. But, Alice Thielgaard concludes from a separate investigation of the personalities of XYY and XXY men that their problems "are not of a magnitude that need concern society in the sense of requiring special precautions".

Altogether a valuable update for those professionally concerned with sex chromosome abnormalities. In addition, anyone interested in the genetics of psychiatric illness might do well to borrow the book and photocopy chapter 19 which contains an elegant review of family studies of affective disorder by Jules Angst. But otherwise not for the general psychiatrist.

ROBIN M. MURRAY, Senior Lecturer, Institute of Psychiatry, London

Trauma and After. Edited by Ruth Porter, JANet PRICE and ROBERT READ. London: Pitman Medical. 1981. Pp 122. £4.95.

Edited Proceedings of a CIBA Foundation Conference for medical students with papers orientated around the title. Topics include parasuicide; grief; accident and emergency work; trauma in industry and battle; brain damage; growing old; childhood cancer. For general medical undergraduates.

SIDNey Crown, Consultant Psychiatrist, The London Hospital

\title{
Correspondence
}

Correspondents should note that space is limited and shorter letters have a greater chance of publication. The Editors reserve the right to cut letters and also to eliminate multitudinous references. Please try to be concise, strictly relevant and interesting to the reader.

\section{MANIA ASSOCIATED WITH WEANING: A HYPOTHESIS}

DEAR SIR,

The report by Joyce et al (October, 1981, 139, 355) of a patient who had suffered two episodes of mania, both of which occurred immediately after cessation of breast feeding, is interesting and invites speculation as to its biological basis. Childbirth has an established aetiological role in cases of post-partum psychosis (Kendell, 1978 and Kendell, 1981), but there is no evidence that cessation of breast-feeding has a similar effect.

After childbirth there are gross changes in the levels of circulating hormones: the levels of prolactin rapidly fall from a level of $200 \mathrm{ng} / \mathrm{ml}$ at term to a baseline normal level of $30 \mathrm{ng} / \mathrm{ml}$ by the end of the first week post-partum. If breast-feeding is started the level of prolactin increases 10 to 20 fold and falls again to baseline level on stopping breast-feeding (Hwang et al, 1971 and Bryant et al, 1972).

It is suggested that the rapid decrease in blood prolactin level that followed weaning was possibly involved in the pathogenesis of this patient's two manic illnesses. This rapid and very significant decrease in blood prolactin level might also act as a trigger in those predisposed to a post-partum psychosis. Dopaminergic mechanisms have been implicated in the control of prolactin secretion (Ed., British Medical Journal, 1975) and prolactin plasma level is a sensitive indicator of the dopaminergic activity of the tuberoinfundibular system. Recent work strongly suggests that the dopaminergic system is overactive in mania (Silverstone, 1979 and Post et al, 1980). Furthermore, prolactin plasma response reflects the blocking effects of major tranquillizers (De La Fuente and Rosenbaum, 1981), a most effective treatment for mania.

Prolactin at high concentrations $(200 \mathrm{ng} / \mathrm{ml})$ has an inhibiting effect on the action of pressor agents (noradrenaline, angiotensin and vasopressin) on arterioles of the rat, (Horrobin et al, 1976) which indicates that prolactin decreases the sensitivity of catecholamine receptors. Animal work however also suggests that prolactin can influence the neuroleptic-induced increase in dopamine receptor sensitivity in the striatum (Perkins and Westfall, 1978 and Hruska et al, 1980). Furthermore, prolactin has recently been shown to interfere with the antipsychotic action of neuroleptics in post-partum psychosis (Goode et al, 1981). These observations highlight the homeostatic function of prolactin in catecholamine receptor function. 
According to Brockington et al (1981) most postpartum psychoses can be classified as manic-depressive psychosis. The incidence of post-partum psychosis in the general population is low (Sim, 1963). Its recurrence rate following childbirth however is high (Reich and Winokur, 1970, and Abou-Saleh and Coppen, unpublished observations).

It is probable that many mothers with a previous history of post-partum psychosis may be discouraged from breast-feeding. If the hypothesis described above is right breast-feeding should rather be encouraged: if prolonged it might prevent the recurrence of the psychosis. It would also be interesting to explore the usefulness of hormonal therapy with prolactin in manic and acute schizophrenic illnesses. The very high levels of blood prolactin following neuroleptic medication might well be serving a therapeutic function.

\section{T. Abou-SAleh}

MRC Neuropsychiatry Research Laboratory,

West Park Hospital,

Epsom, Surrey KT19 8PB

\section{References}

Brockington, I. F., Cernik, K. F., Schofield, E. M., Downing, A. R., Francis, A. F. \& Keelan, C. (1981) Puerperal psychosis: phenomena and diagnosis. Archives of General Psychiatry, 38, 829-33.

Bryant, G. D. \& Greenwood, F. C. (1972) In Lactogenic Hormones, (eds. G. E. W. Wolstenholme and J. Knight), p 197. London: Churchill-Livingstone.

De La Fuente, J. \& Rosenbaum, A. H. (1981) Prolactin in psychiatry. American Journal of Psychiatry, 138, 9, 1154-60.

EdITORIAL (1975) Bromocriptine-A changing scene. British Medical Journal, iv, 667-8.

Goode, D. J., Meltzer, H. Y. \& Fang, V. S. (1981) Increased prolactin levels during phenothiazine and butyrophenone treatment of six post-partum women. Psychoneuroendocrinology, 5, 345-51.

Horrobin, D. F., Mtabaji, J. P. \& Karmali, R. A. (1976) Prolactin and mental illness. Postgraduate Medical Journal, 52, 79-86.

Hruska, R. E., Ludmer, L. M. \& Silbergeld, E. K. (1980) Hypophysectomy prevents the striatal dopamine receptor supersensitivity produced by chronic haloperidol treatment. European Journal of Pharmacology, 65, 455-6.

Hwang, P., Gudya, H. \& Friesen, H. (1971) A radioimmunoassay for human prolactin. Proceedings of the National Academy of Sciences, 68, 1902.

JoyCE, P. R., ROGERS, J. R. M. \& ANDERSON, E. D. (1981) Mania associated with weaning. British Journal of Psychiatry, 139, 355-6.

Kendell, R. E. (1978) Childbirth as an aetiological agent. In Mental Illness in Pregnancy and the Puerperium, (ed. M. Sandler). Oxford Medical Publication.
— Rennie, D., Clarke, J. A. \& Dean, C. (1981) The social and obstetric correlates of psychiatric admission in the puerperium. Psychological Medicine, 11, 341-50.

Perkins, N. A. \& Westrall, T. C. (1978) The effect of prolactin on dopamine release from rat striatum and medial basal hypothalamus. Neuroscience, 3, 59-63.

Post, R. M., Jimerson, D. C., BunNeY, W. E. JNR. \& GoodwIN, F. K. (1980) Dopamine and mania: Behavioural and biochemical effects of the dopamine receptor blocker pimozide. Psychopharmacology, 67, 297-305.

ReICH, T. \& WINOKUR, G. (1970) Post-partum psychosis in patients with manic-depressive disease. Journal of Nervous and Mental Disease, 151, 60-8.

Silverstone, T. (1979) Psychopharmacology of ManicDepressive Illness. In Current Themes in Psychiatry, 3, (eds. R. N. Gaind and B. L. Hudson). London: Macmillan.

SIM, M. (1963) Abortion and the psychiatrist. British Medical Journal, ii, 145.

\section{DEAR SiR,}

\section{ECT AND CEREBRAL DAMAGE}

We wish to dissociate ourselves from the unduly stark comment by our co-authors, Drs Calloway and Dolan, that "we found a statistically significant association between frontal lobe atrophy and previous treatment with ECT" (Journal, January 1982, 140, 103).

Although the statement is correct, it is taken out of context and could lead to faulty interpretation by those who have not read the complete text which is currently in press (Calloway et al, 1982). This paper, essentially a preliminary communication, refers to a small study in which the case notes of 41 elderly depressives who were previously scanned (Jacoby and Levy, 1980) were scrutinized to determine whether or not the patients had ECT in the past and to obtain an estimate of the number of ECT's given. The ECT and non-ECT group were compared on a number of measures of sulcal widening and ventricular size as described in our original paper. There was, indeed, a statistically significant difference in ratings for sulcal widening in the frontal regions between the two groups but this difference did not appear in any of the other regions of the brain and, furthermore, both the global atrophy scoring and the ventricular size was comparable in the two groups. The full paper makes it clear that the retrospective nature of the study must lead to caution in the interpretation of the results and also points to an alternative, non-causal explanation of the association reported.

All that can be said at the moment is that the results are sufficiently interesting to warrant further investigation. They cannot, in our view, be taken as definite 